MATEC Web of Conferences 3, 01038 (2013)

DOI: $10.1051 /$ matecconf/20130301038

(c) Owned by the authors, published by EDP Sciences, 2013

\title{
Estimation of adhesion energy of alumina scales on FeCrAl alloys: effect of the $\mathrm{TiO}_{2}$ sol-gel coating
}

\author{
R. Chegroune, and M. Keddam \\ Laboratoire de Technologie des Matériaux, Faculté G.M et G.P. USTHB, B.P. 32 El-Alia 16111, Alger, Algérie
}

\begin{abstract}
In this work, the effect of sol-gel $\mathrm{TiO}_{2}$ coating on adhesion energy of alumina scales formed on $\mathrm{FeCrAl}$ alloys was investigated. The adhesion energy was evaluated by means of a tensile test in the SEM chamber for the samples oxidized in air at 850 and $950^{\circ} \mathrm{C}$ during $72 \mathrm{~h}$.

In addition, the spallation rate of alumina scales was studied as a function of the imposed longitudinal strain.
\end{abstract}

\section{Introduction}

FeCrAl alloys are extensively used to combat the degradation mechanism where they are exposed to high temperature oxidation. The $\alpha$-alumina scale developed on $\mathrm{FeCrAl}$ alloys is known to be protective against high temperature oxidation [1]. Nevertheless, the $\alpha$-alumina scale can be subjected to cracking and spalling under thermal cycling oxidation [2]. Previous works have shown that reactive elements can improve the protective feature of $\alpha$-alumina and its adherence on the substrate. Efforts have been made in the last years to suppress or reduce the formation of transition aluminas in the temperature range $800-1000^{\circ} \mathrm{C}$. One the effective ways to overcome this problem is to deposit $\mathrm{TiO}_{2}$ films on the oxidized samples from $\mathrm{FeCrAl}$ alloys. This surface treatment promotes the formation of a stable $\alpha$ - alumina scale. To form the $\mathrm{TiO}_{2}$ coatings, the sol-gel technique was adopted in this study since it has an advantage of low cost and rapidity [3]. Among the properties of oxide layers, the adhesion plays an important role since it affects the protective feature of oxide layers. It is well known that doping the alloys with small additions $(<0.1 \mathrm{wt} \%)$ of so called reactive elements (RE) such as $\mathrm{Y}$ or $\mathrm{Zr}$ improve the resistance against spallation. It is also known that, in the absence of RE, a few ppm of sulphur, which exists as a natural impurity in these materials, has a detrimental effect on the scale adhesion [4].

In the current work, the $\mathrm{FeCrAl}$ alloys are oxidized in air at 850 and $950^{\circ} \mathrm{C}$ under an atmosphere of $(\mathrm{Ar}+15 \%$ $\mathrm{O}_{2}$ ). $\mathrm{TiO}_{2}$ sol-gel coating was applied on some oxidized alloys to study its effect on adhesion energy of oxide layers. Adhesion energy of oxide layers were then determined by means of tensile test working in the SEM chamber.

\section{Experimental details}

The investigated materials used for the oxidation tests are from FeCrAl alloys. They are supplied by Thyssen Krupp VDM and Kanthal. Their chemical compositions (in wt. $\%)$, are diplayed in Table 1.

Table 1. Chemical compositions (in wt. \%) of $\mathrm{FeCrAl}$ alloys.

\begin{tabular}{|c|r|r|r|r|r|r|r|}
\hline Alloy & \multicolumn{1}{c|}{$\mathrm{Cr}$} & $\mathrm{Al}$ & $\mathrm{Si}$ & $\mathrm{Hf}$ & $\mathrm{Ti}$ & $\mathrm{Y}$ & $\mathrm{Zr}$ \\
\hline YHfs1 & 20.15 & 6.02 & & 0.045 & 0.004 & 0.065 & 0.058 \\
\hline YHf & 19.65 & 5.53 & 0.29 & 0.031 & 0.0098 & 0.046 & 0.054 \\
\hline $\mathrm{M}_{1}$ & 19.9 & 5.0 & 0.002 & $\cdots$ & $\cdots$ & $\cdots$ & $\cdots$ \\
\hline A.PM & 21 & 5.8 & 0.4 & 0.00011 & 0.021 & 0.00001 & 0.11 \\
\hline
\end{tabular}

$\mathrm{TiO}_{2}$ sol-gel films were prepared from the TIPT precursor using a procedure close to that proposed in reference [5]. Oxidation of treated FeCrAl samples was carried out in a horizontal furnace under an atmosphere of $\left(\mathrm{Ar}+15 \% \mathrm{O}_{2}\right)$. Non-treated samples were also systematically oxidized in all runs. The adhesion energy $G\left(\mathrm{~J} / \mathrm{m}^{2}\right)$ given by Equation (1) was determined by a forced spallation of the oxide scale from the tensile test in the SEM chamber.

$G=W \times e$

where $W$ represents the elastic energy stored per volume unit $\left(\mathrm{J} / \mathrm{m}^{3}\right)$ in the oxide layer and $e$ is the oxide layer thickness (m).

The samples, used for estimating the quantity $G$, were oxidized in air at 850 and $950{ }^{\circ} \mathrm{C}$ for $72 \mathrm{~h}$. The oxidized samples were cooled down to ambient temperature and placed in the SEM chamber for the tensile tests at a deformation speed of $20 \mu \mathrm{m} / \mathrm{s}$. 


\section{Experimental results}

In Figure 1 is shown the top-view of SEM micrograph of the surface of the oxidized YHf alloy in air at $850^{\circ} \mathrm{C}$ during $72 \mathrm{~h}$ after a unidirectional tensile test.

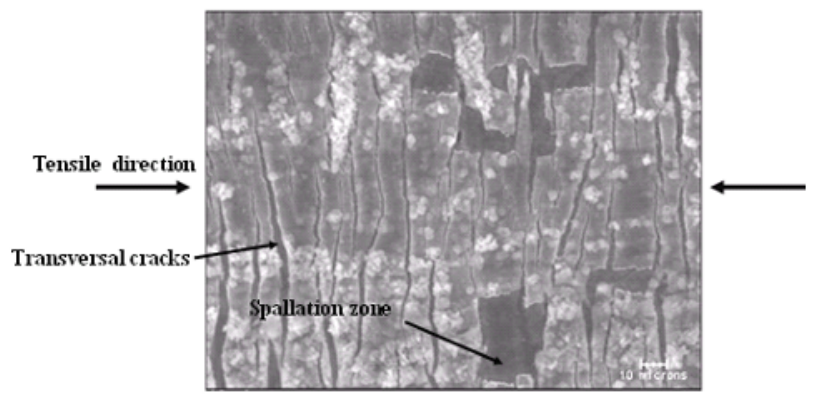

Figure 1. SEM micrograph of the surface of the YHf sample oxidized in air at $850^{\circ} \mathrm{C}$ for $72 \mathrm{~h}$ after a unidirectional tensile test.

The variation of the estimated value of rate spallation at each imposed strain is presented in Figure 2 for the oxidized samples from $\mathrm{FeCrAl}$ alloys at two temperatures: 850 and $950^{\circ} \mathrm{C}$ during $72 \mathrm{~h}$.

Figure 2 (A) shows that the spallation rate determined on the oxidized YHf sample is almost stationary. The low rate spallation at $950^{\circ} \mathrm{C}$ (Figure 2 (B)) compared to that obtained at $850^{\circ} \mathrm{C}$ can be explained by the rapid relaxation of the induced stresses in the oxide layer [6].
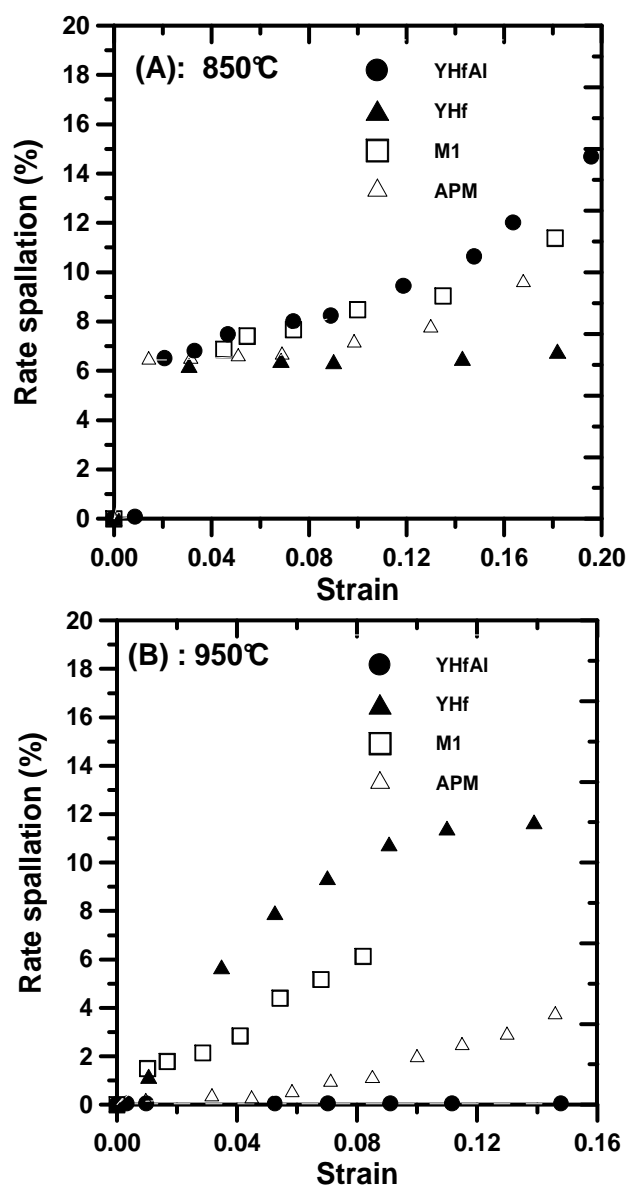

Figure 2. Evolution of the rate spallation as a function of the imposed strain: (A) oxidation in air at $850^{\circ} \mathrm{C},(\mathrm{B})$ oxidation in air at $950^{\circ} \mathrm{C}$.
The first scales appeared on the surfaces of oxidized samples (YHf, YHfAl, APM and $\mathrm{M}_{1}$ ) at $950^{\circ} \mathrm{C}$ for the low values of imposed longitudinal strains contrarily to those observed on the surfaces of oxidized samples at $850^{\circ} \mathrm{C}$. As an example, the results of spallation rates, obtained for an imposed strain of $5 \%$, on the oxidized samples at 850 and $950^{\circ} \mathrm{C}$ are gathered in Table 2.

Table 2. Values of spallation rates obtained for an imposed strain of $5 \%$.

\begin{tabular}{|l|c|c|}
\hline FeCrAl Alloys & $850^{\circ} \mathrm{C}$ & $950^{\circ} \mathrm{C}$ \\
\hline YHf & 6.23 & 7.86 \\
\hline YHfAl & 7.41 & 0 \\
\hline APM & 6.46 & 0.43 \\
\hline M1 & 7.41 & 4.35 \\
\hline
\end{tabular}

The critical spallation strain is an important characteristic when evaluating the adhesion energy. In Table 3 , it is noticed that the values of adhesion energy of the formed oxides at $950^{\circ} \mathrm{C}$ are lower than those of the formed oxides at $850^{\circ} \mathrm{C}$, excepted for the oxidized YHfAl alloy. The high value of adhesion energy $\left(1263 \mathrm{~J} / \mathrm{m}^{2}\right)$ estimated at $950^{\circ} \mathrm{C}$ on the oxidized YHfAl alloy is in contradiction with the result obtained on other oxidized samples.

This fact can be attributed to the progressive transformation of transition aluminas to stable $\alpha$-aluminas, caused by the volume contraction. After the oxidation tests in air at $850^{\circ} \mathrm{C}$ for $65 \mathrm{~h}$, two YHfAl samples with and without the $\mathrm{TiO}_{2}$ coating are subjected to the tensile test in the SEM chamber.

SEM micrographs of the surfaces of the oxidized YHfAl alloys in air at $850^{\circ} \mathrm{C}$ for $65 \mathrm{~h}$ with and without $\mathrm{TiO}_{2}$ film are displayed in Figure 3.

Table 3. Values of elastic and adhesion energies of the aluminas scales formed on $\mathrm{FeCrAl}$ alloys at 850 and $950^{\circ} \mathrm{C}$.

\begin{tabular}{|l|l|c|c|}
\hline $\begin{array}{l}\mathrm{T} \\
\left({ }^{\circ} \mathrm{C}\right)\end{array}$ & $\begin{array}{l}\text { FeCrAl } \\
\text { Alloys }\end{array}$ & $\begin{array}{c}\text { Elastic energy } \\
(\mathrm{MJ} / \mathrm{m})\end{array}$ & $\begin{array}{c}\text { Adhesion energy } \\
\left(\mathrm{J} / \mathrm{m}^{2}\right)\end{array}$ \\
\hline \multirow{5}{*}{850} & YHf & 181 & 253 \\
\cline { 2 - 4 } & YHfAl & 212 & 339 \\
\cline { 2 - 4 } & APM & 977 & 1271 \\
\cline { 2 - 4 } & M & 415 & 332 \\
\hline \multirow{5}{*}{950} & YHf & 827 & 15 \\
\cline { 2 - 4 } & YHfAl & 901 & 1263 \\
\cline { 2 - 4 } & APM & 195 & 411 \\
\cline { 2 - 4 } & M & 18 & 7 \\
\hline
\end{tabular}


The transversal cracks after the tensile tests are visible on the both oxidized surfaces. The density of theses cracks is found to be important when applying the $\mathrm{TiO}_{2}$ film on the surface of the oxidized YHfAl alloy.
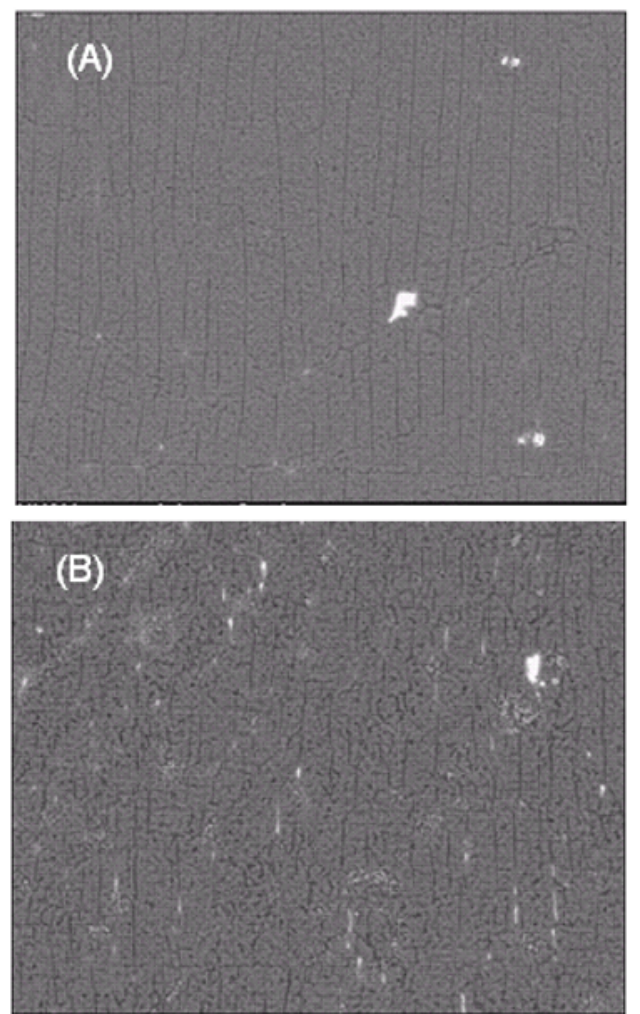

Figure 3. SEM micrographs of the surfaces of the YHfAl alloys oxidized in air at $850^{\circ} \mathrm{C}$ for $65 \mathrm{~h}$ after a tensile test: (A) Non coated sample, (B) coated sample with $\mathrm{TiO}_{2}$ film.

Evolution of the spallation rate versus the imposed strain for the two samples (with and without the $\mathrm{TiO}_{2}$ coating), is shown in Figure 4.

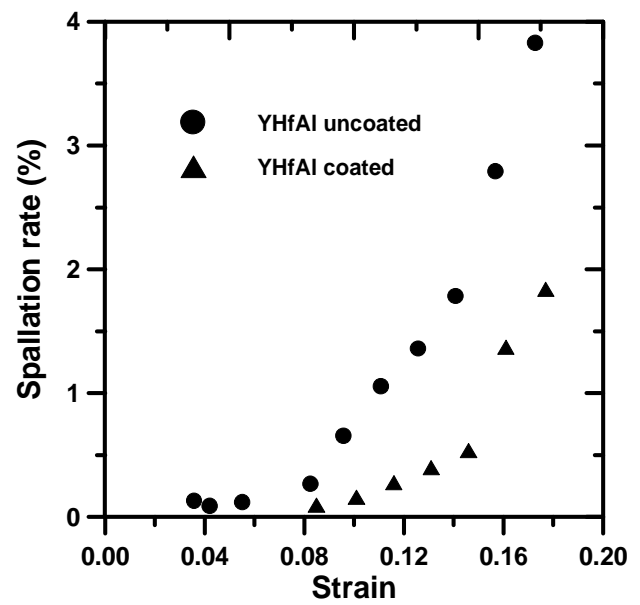

Figure 4. Influence of $\mathrm{TiO}_{2}$ coating on the variation of spallation rate of YHfAl samples as a function of the applied longitudinal strain.

It is found that the oxidized samples without $\mathrm{TiO}_{2}$ film spalled at a strain lower than $4 \%$. The scales appeared at a strain value of $8.6 \%$ for the coated sample. The application of $\mathrm{TiO}_{2}$ film contributed to reduce the transition aluminas by forming the $\alpha$-aluminas which are adherent to the substrate [7]. The value of adhesion energy was estimated as $2145 \mathrm{~J} / \mathrm{m}^{2}$ for the coated sample with $\mathrm{TiO}_{2}$ film, while it was only $475 \mathrm{~J} / \mathrm{m}^{2}$ for the noncoated sample oxidized at $850^{\circ} \mathrm{C}$ during $65 \mathrm{~h}$.

\section{Conclusion}

From the present work, the following concluding point can be drawn as follows:

1) $\mathrm{TiO}_{2}$ sol-gel deposit on $\mathrm{FeCrAl}$ alloys constitutes an efficient surface treatment to reduce the presence of transition aluminas.

2) The aluminas formed on the $\mathrm{FeCrAl}$ alloys at $950^{\circ} \mathrm{C}$ exhibited a low adhesion on the substrate.

3) The value of adhesion energy was estimated as $2145 \mathrm{~J}$ $/ \mathrm{m}^{2}$ for the coated sample with $\mathrm{TiO}_{2}$ film, while it was only $475 \mathrm{~J} / \mathrm{m}^{2}$ for the non-coated sample oxidized at $850^{\circ} \mathrm{C}$ during $65 \mathrm{~h}$.

\section{References}

1. T. Biegun, M. Danielewski, Z. Skrzypek, Oxid. Met. 38207 (1992)

2. V.K. Tolpygo, Oxid. Met. 51449 (1999)

3. L.V. Ramanathan, M.F. Pillis, S.M.C. Fernandes, J. Mater. Sci. 43(2) 530 (2008)

4. C. Mennicke, E. Schumann, C. Ulrich, M. Ruhle, Mater. Science Forum 251-254 389 (1997)

5. M. Langlet, M. Burgos, C. Coutier, C. Jimenez, C. Morant, M. Manso, J. Sol-Gel Sci. Technol. 22139 (2001)

6. R. Chegroune, M. Keddam, E. N'Dah, A. Galerie, Mater. et Tech. 2013 (2013)

7. R. Chegroune, M. Keddam, Y. Wouters, A. Galerie, E.Salhi, Applied Surf. Sci. 2573929 (2011) 